\title{
Immunomodulatory and hypoallergenic properties of milk protein hydrolysates in ICR mice
}

\author{
D. D. Pan, ${ }^{*} \dagger^{1}$ Z. Wu, $\dagger$ J. Liu, ${ }^{*}$ X. Y. Cao, ${ }^{*}$ and X. Q. Zeng ${ }^{*}$ \\ *Food Science and Technology Department of the Marine Science School, Ningbo University, Ningbo 315211, P. R. China \\ †Food Science and Nutrition Department of Ginling College, Nanjing Normal University, Nanjing 210097, P. R. China
}

\begin{abstract}
Approximately $2.5 \%$ of young children are allergic to cow milk. In this study, milk protein hydrolysates made from full-cream milk via enzymatic hydrolysis played a positive role in regulating the immune system of ICR mice. Milk protein hydrolysates enhanced immunity in mice by stimulating host immunity, probably by increasing the weight of certain immune system organs, improving the level of hemolysin in serum, and enhancing the phagocytosis of macrophages. Milk protein hydrolysates have the capability to reduce type I hypersensitivity by decreasing IgE levels, IL-4 in serum, and the release of histamine and bicarbonate in peritoneal mast cells, as well as enhancing transforming growth factor- $\beta$ levels in the serum of ovalbumin-sensitized mice.
\end{abstract}

Key words: milk protein hydrolysate, ICR mice, immunomodulatory, allergenicity

\section{INTRODUCTION}

Dairy products are one of the finest carriers of bioactive compounds, including natural bioactive and milkgrowth peptides. Dairy products all have the capacity to affect the body's major systems, including the cardiovascular, digestive, endocrine, immune, and nervous systems, by producing intracellular signals that modify nutrient uptake, DNA synthesis, and cell division (Korhonen, 2009). Research has found that immune factors, such as IgG and IgA in colostrum and milk, play an important role in the host defense of the mammary gland itself, protecting it from pathogenic organisms (Playford et al., 2000; Oviedo-Boyso et al., 2007).

Nevertheless, dairy milk proteins are also well known for causing allergic reactions in many infants and adults (Caffarelli et al., 2010). Milk proteins are extensively hydrolyzed during gastrointestinal digestion before they are transferred to the basolateral side of the intestinal

Received March 5, 2013.

Accepted April 23, 2013.

${ }^{1}$ Corresponding author: daodongpan@163.com enterocytes and then released into the interstitial space and absorbed (Høst et al., 1999). Milk protein is usually the first source of foreign antigens that infants ingest in large quantities, although the infant intestinal system is insufficiently developed to digest and immunologically react to milk proteins (Caira et al., 2012). Allergies to cow milk are characterized by hypersensitivity to casein or whey, which affects about 2 to $3 \%$ of young infants. Several possible explanations exist for allergic reactions to dairy products. The pathogenesis of allergies to milk involves IgE or non-IgE-mediated reactions in the skin, lungs, and gastrointestinal tract (Shek et al., 2005). Among IgE-mediated allergic reactions, $\beta$-LG, derived from bovine whey proteins, is one of the most prevalent allergens, as evidenced by oral challenges, skin scratch, and skin prick tests (Gordon et al., 2013). For nonIgE-mediated hypersensitivity, it is likely that several mechanisms operate in each patient.

Given that dairy products are one of the finest carriers of bioactive compounds and the main nutrition resource for infants, efforts should be undertaken to develop milk proteins that contain more trophic value, but with lower allergenicity. Various milk proteins and their enzymatically derived peptides have demonstrated modulating effects in vitro, including lymphocyte activation and proliferation (Picariello et al., 2010). Some clinical trials in hypertensive animals and humans have shown that casein- and whey protein-derived peptides can markedly reduce hypertension. Colostrum and milk-derived peptides contain growth factors for the treatment of gastrointestinal disorders (Eriksen et al., 2008). However, great uncertainty exists about whether milk-derived peptides are involved in immunity and hypoallergenicity.

Protein hydrolysates produced from protein sources by heating with acid, alkali, or enzymes, followed by purification, have been studied (Silvestre, 1997). During alkali and acid hydrolysis, Cys and Met may be oxidized, and some Ser and Thr destroyed, whereas Gln and Asn are converted into glutamate and aspartate, respectively, usually reducing protein quality and biologic value. The present study focused on milk protein hydrolysates (MPH) made from full-cream milk via 
enzymatic hydrolysis (papain and trypsin). Our study was conducted to better understand MPH immunomodulating and hypoallergenic mechanisms through the use of in vivo animal trials. Based on dietary trials in ICR mice, we hope our study can provide evidence for the use of MPH in the functional food industry in the near future.

\section{MATERIALS AND METHODS}

\section{Reagents}

Full-cream milk powder was purchased from Erie Inc. (Nei Monggol, China). Percoll was purchased from the Sigma-Aldrich Company (Shanghai, China). Thioglycollate medium was purchased from Hope Biol-Technology (Qingdao, China). Ovalbumin (OVA), Indian ink, and sheep and chicken red blood cells were purchased from Solarbio (Beijing, China). Enzyme-linked immunosorbent assay kits were obtained from Nanjing JianCheng Bioengineering Institute (Nanjing, China). All other chemical reagents were analytical reagent grade.

\section{MPH Preparation}

The MPH was made from full-cream milk via enzymatic hydrolysis. Optimized factors for obtaining the highest peptide content were an enzymatic mixture of papain (EC 3.4.22.2) and trypsin (EC 3.4.21.4; 1:1, E/S $=1 / 600$ ) with a $\mathrm{pH}$ close to 7.08 at $37^{\circ} \mathrm{C}$ for $4 \mathrm{~h}$, which is better for the production of MPH (Cao et al., 2012). To keep the constant $\mathrm{pH}, 0.5 \mathrm{M}$ of $\mathrm{NaOH}$ was added every $30 \mathrm{~min}$. Under these conditions, the concentration of peptide content was up to $2.38 \mathrm{mg} / \mathrm{mL}$. Meanwhile, allergic reactions to $\alpha$-LA and $\beta$-LG were decreased by 70.2 and $89.8 \%$ compared with full-cream milk. The soluble milk protein peptides $(<10 \mathrm{kDa})$ were isolated in a UF tube $(15 \mathrm{~mL}$; molecular weight cutoff $=10$ $\mathrm{kDa})$ at $12,000 \times g$ for 5 min. After that, MPH was freeze-dried and stored at $-20^{\circ} \mathrm{C}$ for further study.

\section{Animals and Treatment}

The ICR mice (8-wk-old, weighing $20 \pm 2$ g) were purchased from the Experimental Animal Center, Zhejiang Medical University (Hangzhou, China). All animal procedures were performed in accordance with the ethical guidelines for animal care at Ningbo University, and provided with water and standard food. During the experimental procedure, mice were divided into 4 groups, with each group consisting of 10 mice (5 male and 5 female), and housed in separate rooms. The control group was orally given a control diet (normal saline alone); $3 \mathrm{MPH}$ treatment groups (I, II, III) were given MPH doses of 150 (I), 300 (II), and 600 (III) mg/ $\mathrm{kg}$ of BW per day, respectively. All groups were treated daily for 25 consecutive days (Nakamura et al., 2011; Amdekar et al., 2012).

\section{Spleen and Thymus Indexes and Serum Hemolysin Levels}

Twenty-five days after the commencement of oral administration all rats were weighed and euthanized under ether anesthesia, at which time the spleen and thymus were collected for analysis. The thymus and spleen indices (\%) were calculated by

$$
\begin{aligned}
& \text { Spleen index }=\frac{W_{1}}{W_{0}} \times 100, \text { and } \\
& \text { Thymus index }=\frac{W_{2}}{W_{0}} \times 100,
\end{aligned}
$$

where $W_{1}$ is the spleen weight; $W_{2}$ is the thymus weight; and $W_{0}$ is BW.

The hemolysin content in the serum was assessed using a half hemolysin value $\left(\mathrm{HC}_{50}\right)$ assay (Chen et al., 2012). Mice were sensitized with $20 \%$ (vol/vol) sheep red blood cells (SRBC; $200 \mu \mathrm{L} / \mathrm{d}$ ) for $4 \mathrm{~d}$. Serum was separated from blood and diluted 500-fold with PBS. One milliliter of diluted serum was incubated at $37^{\circ} \mathrm{C}$ for $30 \mathrm{~min}$ with $0.5 \mathrm{~mL}$ of $5 \%$ ( $\mathrm{vol} / \mathrm{vol}$ ) SRBC suspension and $0.5 \mathrm{~mL}$ of $10 \%$ guinea pig serum. The reaction was stopped in an ice-bath and the solution was centrifuged at $1,000 \times g$ for $10 \mathrm{~min}$. One milliliter of supernatant was mixed with $3 \mathrm{~mL}$ of Drabkin's solution $(1.19 \mathrm{mM}$ $\mathrm{NaHCO}_{3}, 0.07 \mathrm{~m} M \mathrm{KCl}$, and $0.06 \mathrm{~m} M$ potassium ferricyanide) and the optical density (OD) was measured at $540 \mathrm{~nm}\left(\mathrm{OD}_{1}\right)$. Similarly, the $\mathrm{OD}_{2}$ of the $\mathrm{SRBC}$ was measured as $4 \mathrm{~mL}$ of Drabkin's solution added to 250 $\mu \mathrm{L}$ of $5 \%$ ( $\mathrm{vol} / \mathrm{vol}$ ) SRBC and measured at $540 \mathrm{~nm}$. The index of serum $\mathrm{HC}_{50}(\%)$ was calculated as

$$
\mathrm{HC}_{50}=\frac{\mathrm{OD}_{1}}{\mathrm{OD}_{2}} \times 100
$$

\section{Determination of Macrophage Phagocytic Function}

For a carbon clearance test, the mice (25 d) were injected intravenously via the lateral tail vein with Indian ink $(0.5 \mathrm{~mL})$. Blood samples $(20 \mu \mathrm{L})$ were collected from the orbital venous plexus at $2 \mathrm{~min}\left(\mathrm{t}_{1}\right)$ and $10 \mathrm{~min}$ $\left(t_{2}\right)$, respectively (Mahajan and Mehta, 2010). Blood samples were then mixed with $2 \mathrm{~mL}$ of $0.1 \%$ sodium carbonate solution in tubes to measure the $\mathrm{OD}$ value at 
$600 \mathrm{~nm}$. The clearance index and $k$ values (representing the carbon granule clearance capability from mouse blood) were calculated by

$$
\begin{gathered}
k=\frac{\lg \mathrm{OD}_{1}-\lg \mathrm{OD}_{2}}{\mathrm{t}_{2}-\mathrm{t}_{1}}, \text { and } \\
\text { Clearance index }(\alpha)=W_{0} \times \frac{\sqrt[3]{k}}{W_{a}+W_{b}},
\end{gathered}
$$

where $\mathrm{OD}_{1}$ is the measured value of the sample at $t_{1}$; $\mathrm{OD}_{2}$ is the measured value of the sample at $\mathrm{t}_{2} ; k$ is the adjusted phagocytic index; $W_{a}$ is the liver weight; $W_{b}$ is the spleen weight; and $W_{0}$ is BW.

A chicken red blood cell (CRBC) test was used according to $\mathrm{Wu}$ et al. (2012), with some modifications. For the assay, $1.5 \mathrm{~mL}$ of $3 \%$ thioglycollate medium was injected intraperitoneally into mice $(25 \mathrm{~d})$. Three days later, $1 \mathrm{~mL}$ of $2 \%$ CRBC suspension was injected intraperitoneally into mice abdominal cavities, and then peritoneal lavage was performed with $3 \mathrm{~mL}$ of Hanks' solution for $10 \mathrm{~min}$. Activated macrophages were obtained and placed on a microscope slide. After incubation in a humidified $5 \% \mathrm{CO}_{2}$ incubator at $37^{\circ} \mathrm{C}$ for 30 min, the slide was dried and washed with PBS ( $\mathrm{pH} 7.2)$ to remove nonadherent cells. Adherent cells were dyed with Wright's stain and counted. The phagocytosis percentage was measured by counting the number of macrophages phagocytosing CRBC per 100 macrophage cells. The phagocytosis index was measured using the ratio of total number of phagocytosed CRBC to the total number of macrophages.

\section{IgG, IgE, IL-4, and Transforming Growth Factor- $\beta$ Measurement in Serum}

The concentrations of IgG, IgE, IL-4, and transforming growth factor (TGF)- $\beta$ were measured with a commercial ELISA kit assay according to the manufacturer's directions.

\section{Determination of Histamine and Bicarbonate In Vivo}

The number of collected peritoneal mast cells (PMC) in the suspension was adjusted to $1 \times 10^{5}$ cells $/ \mathrm{mL}$ for the histamine release experiment according to the method of Ogawa et al. (1999), with some modification. Histamine release was reduced by adding $0.5 \mathrm{~mL}$ of OVA $(5 \mathrm{mg} / \mathrm{mL})$ to $0.5 \mathrm{~mL}$ of cell suspension, followed by incubation at $37^{\circ} \mathrm{C}$ in a humidified $5 \% \mathrm{CO}_{2}$ incubator for $1 \mathrm{~h}$. The mixture was centrifuged directly $(12,000$ $\left.\times g, 4^{\circ} \mathrm{C}, 15 \mathrm{~min}\right)$ and the supernatant was collected as the egg albumin-induced histamine release group
(G1), whereas the centrifuged supernatant hot-treated $\left(100^{\circ} \mathrm{C}, 1 \mathrm{~min}\right)$ mixture was collected as the total histamine release group (G2). The clear supernatant of both groups $(0.5 \mathrm{~mL})$ was added to $0.5 \mathrm{~mL}$ of $\mathrm{NaOH}(0.4 M)$ and followed by $0.1 \mathrm{~mL}$ of $74.55 \mathrm{~m} M$ phthaldialdehyde and mixed immediately. The reaction was stopped after 10 min by adding $0.5 \mathrm{~mL}$ of $\mathrm{HCl}(0.4 \mathrm{M})$. The fluorescence of the histamine in both groups was measured by Microplate Fluorescence Reader (ApectraMax-M2, Molecular Devices, Shanghai, China) emission at 422 $\mathrm{nm}$ with excitation at $365 \mathrm{~nm}$. The histamine release rate is expressed as the percentage of histamine in G1 compared with the histamine in G2. Meanwhile, the bicarbonate level in the PMC suspension was also measured according to Godkar (1996), with slight modification.

\section{Statistical Analysis}

All results obtained are expressed as the mean $\pm \mathrm{SD}$. The statistical analyses of the data were performed using SPSS Statistics 17.0 software (SPSS Inc., Chicago, IL). Using Student's t-test, $P<0.05$ was considered statistically significant.

\section{RESULTS AND DISCUSSION}

\section{Effect of MPH on Thymus and Spleen Weight}

As shown in Table 1, the spleen and thymus indices increased in a concentration-dependent manner in the $\mathrm{MPH}$ treatment groups. Compared with the normal control group, the spleen and thymus indices increased significantly in group III. The spleen and thymus indices in the male group were higher than in the female group. No obvious effect of MPH on the spleen and thymus indices was observed in group I. The results indicated that MPH increased the weight of immune system organs in vivo. The thymus is a central immune system organ with both endocrine and immune functions (Stelwagen et al., 2009). The spleen is the largest secondary lymphoid organ in the host immune system, which is responsible for initiating immune reactions to blood-born antigens, and it can filter foreign material from blood (Ohta et al., 2012). Therefore, the spleen is more sensitive to MPH stimulation, as shown by the finding that the spleen index was higher than the thymus index in the mice.

The MPH intake markedly increased hemolysin in both male and female mice (groups I, II, and III) compared with the control group; no significant difference was observed between the male and female groups. Serum hemolysin, a kind of specific antibody, is an important indicator of human immunity. The level of serum 
Table 1. Effect of milk protein hydrolysates on the immune organs of mice ${ }^{1}$

\begin{tabular}{|c|c|c|c|c|}
\hline Group & $\begin{array}{l}\text { Milk protein } \\
\text { hydrolysate } \\
\text { dose }(\mathrm{mg} / \mathrm{kg})\end{array}$ & $\begin{array}{l}\text { Spleen index } \\
(\%)\end{array}$ & $\begin{array}{c}\text { Thymus index } \\
(\%)\end{array}$ & $\begin{array}{c}\text { Half hemolysin } \\
\text { value }(\%)\end{array}$ \\
\hline Control & 0 & $0.39 \pm 0.07$ & $0.19 \pm 0.07$ & $60.02 \pm 5.896$ \\
\hline I (Q) & 150 & $0.40 \pm 0.05$ & $0.21 \pm 0.03$ & $66.43 \pm 2.404$ \\
\hline II (Q) & 300 & $0.45 \pm 0.06^{*}$ & $0.26 \pm 0.06$ & $75.82 \pm 3.917^{*}$ \\
\hline III (ㅇ) & 600 & $0.55 \pm 0.15^{* *}$ & $0.27 \pm 0.05^{*}$ & $86.08 \pm 3.427^{* *}$ \\
\hline I $\left(\mathrm{O}^{7}\right)$ & 150 & $0.42 \pm 0.02$ & $0.23 \pm 0.03$ & $68.43 \pm 3.312$ \\
\hline II $\left(0^{7}\right)$ & 300 & $0.48 \pm 0.04^{*}$ & $0.28 \pm 0.04$ & $77.82 \pm 2.836^{*}$ \\
\hline III $\left(O^{7}\right)$ & 600 & $0.61 \pm 0.11^{* *}$ & $0.31 \pm 0.05^{*}$ & $89.08 \pm 3.925^{* *}$ \\
\hline
\end{tabular}

${ }^{1}$ Values are means \pm SEM $(\mathrm{n}=5)$.

${ }^{*} P<0.05 ;{ }^{* *} P<0.01$ vs. control group.

hemolysin in a body is the main nonspecific indicator of immune function, reflecting hemolytic B cell proliferation and differentiation, as well as complement binding to the hemolysin-induced secretion of body fluids (Zaleski et al., 1995). In measuring hemolysin, we sought to detect the host's defensive immune capability. The results above indicate that MPH can improve immunity by triggering hemolysin formation and, thereby, increase immunologic function in mice.

\section{Effect of MPH on Phagocytosis of Macrophages}

To elucidate the effect of MPH on macrophage phagocytic function, carbon clearance and CRBC tests were undertaken. Table 2 shows the $k$, $\alpha$ value, phagocytosis index, and phagocytosis percentage from mice pretreated in different ways. Compared with the control group, MPH has great influence on the phagocytosis of macrophages (Table 2). When MPH concentration increased from 150 to $300 \mathrm{mg} / \mathrm{kg}$, the $k$, a value, and phagocytosis percentage and index all increased in a dose-dependent manner - especially the $k$ value in group III, which increased by $178.8 \%$ compared with the control group. In all multicellular organisms, macrophages represent the first line of host defense after the epithelial barrier (Cheng et al., 2010). According to Thakur et al. (2006), the faster removal of carbon par- ticles from blood is related to an increase in phagocytic activity. These results suggest that MPH may enhance immunity by strengthening macrophage phagocytosis.

\section{Effects of MPH on IgE, IgG, IL-4 and TGF- $\beta$ Levels in Mice Serum}

As illustrated in Figure 1A, the level of IgG in serum from groups I, II, and III did not show any significant difference compared with the model group. The IgE value of the model group treated with $100 \mu \mathrm{g}$ of OVA increased significantly $(P<0.01)$ compared with the control group. Levels of $\mathrm{IgE}$ in serum from groups I, II, and III significantly decreased compared with the model group (Figure 2B). The trend of IL-4 in Figure $2 \mathrm{C}$ is similar to IgE. Also called the reaginic antibody, $\operatorname{IgE}$ generally presents increased levels in individuals with allergies. When cells, such as mucous membrane or skin cells, are attached to IgE, they become sensitized to allergens (Johansson et al., 2001).

Immunoglobulin $\mathrm{G}$ is the most abundant immunoglobulin class in serum and the major antibody in the secondary humoral immune response. Furthermore, IgG serves to activate the complement system and is frequently involved in opsonization (Kessel and Dalal, 2011). These results reveal that the sensitization induced by OVA can be attributed to IgE, not IgG. Some

Table 2. Effect of milk protein hydrolysates on phagocytosis of macrophages ${ }^{1}$

\begin{tabular}{|c|c|c|c|c|}
\hline Group $^{2}$ & $k$ & $\alpha$ & $\begin{array}{c}\text { Phagocytosis } \\
(\%)\end{array}$ & $\begin{array}{l}\text { Phagocytosis } \\
\text { index }\end{array}$ \\
\hline Control & $0.0430 \pm 0.007$ & $6.8472 \pm 0.582$ & $24.16 \pm 2.462$ & $0.290 \pm 0.029$ \\
\hline & $0.0449 \pm 0.020$ & $6.8158 \pm 0.741$ & $26.92 \pm 2.059$ & $0.290 \pm 0.024$ \\
\hline II & $0.0698 \pm 0.011^{\mathrm{a}}$ & $8.3468 \pm 0.213^{\mathrm{a}}$ & $32.02 \pm 3.805^{\mathrm{ab}}$ & $0.348 \pm 0.035^{\mathrm{ab}}$ \\
\hline III & $0.0769 \pm 0.010^{\mathrm{ab}}$ & $8.9029 \pm 1.027^{\mathrm{ab}}$ & $36.52 \pm 2.155^{\mathrm{b}}$ & $0.390 \pm 0.033^{\mathrm{b}}$ \\
\hline
\end{tabular}



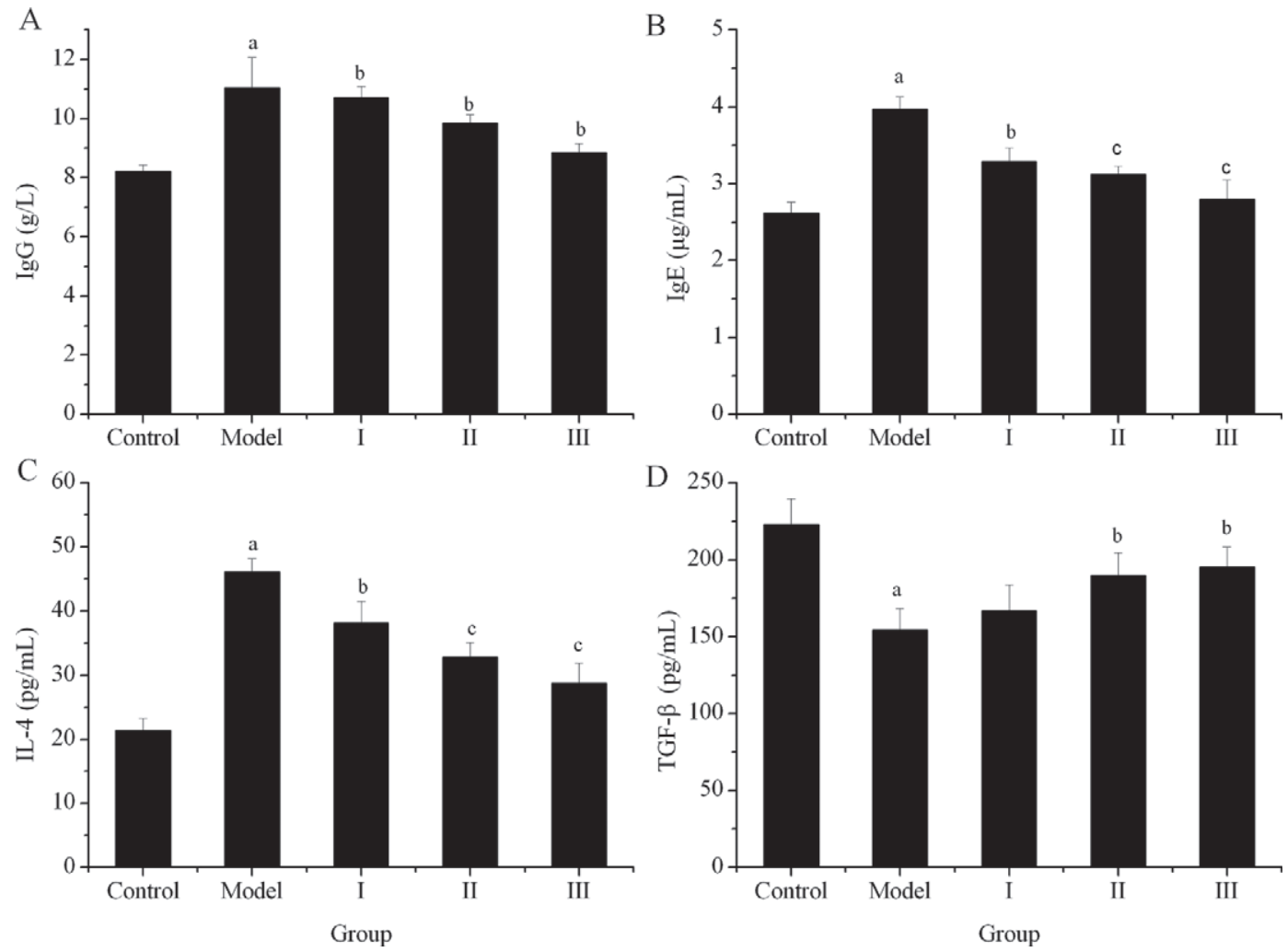

Figure 1. Effect of milk protein hydrolysates (MPH) on IgG, IgE, IL-4, and transforming growth factor- $\beta$ (TGF- $\beta$ ) levels in serum of mice. Control group was treated with saline alone. Groups I, II, and III were treated with MPH at 150, 300, and $600 \mathrm{mg} / \mathrm{kg}$ of BW per day, respectively. Values are means \pm SEM $(\mathrm{n}=10)$. Different letters indicate significant differences among results: $\mathrm{a}=P<0.01$ vs. control group; $\mathrm{b}=$ $P<0.05 ; \mathrm{c}=P<0.01$ vs. model group.

research has shown that IgE- but not IgG-mediated anaphylaxis induces large increases in IL-4 secretion (Khodoun et al., 2011). It also appears that MPH has the capability to reduce type I hypersensitivity by lowering the $\operatorname{IgE}$ concentration in serum.

As shown in Figure 1D, the TGF- $\beta$ concentration in the model group significantly decreased, which may promote an allergic reaction. Significantly, an increase in TGF- $\beta$ levels in serum was shown in the MPHtreated mice compared with the model group, except when $\mathrm{MPH}$ were administered at a dose of $100 \mathrm{mg} / \mathrm{kg}$ (group I). During an allergic reaction, IL-4 can enhance B cell IgE production. Transforming growth factor- $\beta$ is one of the cytokines that has an inhibitory function (Komai-Koma et al., 2012).

Food allergies can cause a Th2 cytokine imbalance, exhibiting a specific immune response and promoting $\mathrm{T}$ cells to produce IL- 4 . Then, IL- 4 can promote B-cell proliferation, differentiation, and antibody formation (Gavett et al., 1995). In a previous study, it was shown that TGF- $\beta$ plays a significant role in normal immune and allergic responses. The results indicate that the increased levels of $\lg \mathrm{E}$ in sensitized mice may be due to increased concentrations of IL-4 in the serum. After the sensitized mice were treated with MPH, the level of IL- 4 and TGF- $\beta$ gradually approached that of the control group (from group I to III).

\section{Histamine and Serum Bicarbonate Examination in Mice PMC}

Mast cells, which mediated the release of histamine and heparin, play a key role in the inflammatory process. Histamine is an important protein involved in many allergic reactions. For an allergic reaction to occur, cell surface receptors on mast cells must first attach to a free-floating IgE molecule specific to the antigen. Antigen binding to the mast cell-attached $\operatorname{IgE}$ then triggers a mast cell response. The release of histamine is often included in this response (Sugimoto et al., 1998). As shown in Figure 2A, the increase in directional histamine release percentage from sensitized mast cells was significant in model group mice compared with the control group, which proved that mast cells were activated and that sensitization modeling was successful. Compared with the model group, the histamine release 

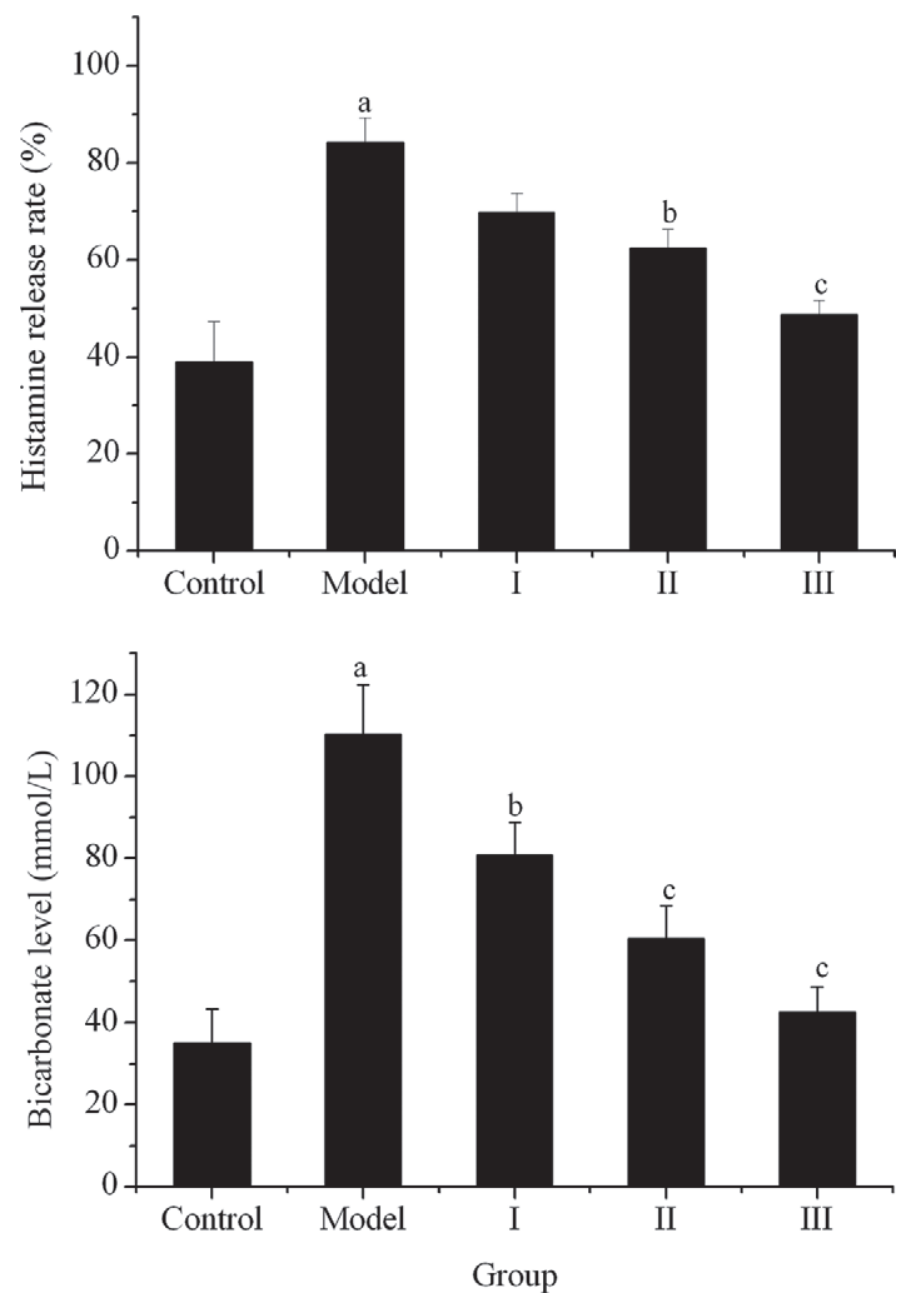

Figure 2. Effect of milk protein hydrolysates (MPH) on the release of histamine and bicarbonate in peritoneal mast cells. The control group was treated with normal saline alone. Groups I, II, and III were treated with $\mathrm{MPH}$ at 150,300 , and $600 \mathrm{mg} / \mathrm{kg}$ of BW per day, respectively. Values are means $\pm \operatorname{SEM}(\mathrm{n}=10)$. Different letters indicate significant differences among results: $\mathrm{a}=P<0.01$ vs. control group; $\mathrm{b}=P<0.05 ; \mathrm{c}=P<0.01$ vs. model group.

percentage in the MPH treatment group decreased in a dose-dependent manner, and the histamine percentage in group III gradually approached the level of the control group.

In OVA-stimulated PMC, significantly $(P<0.001)$ higher levels of histamine and bicarbonate were observed in the model group than in the control group (Figure 2B). Bicarbonate levels decreased significantly in ICR mice exposed to different concentrations of MPH. Vilariño et al. (1999) suggested that bicarbonate may modulate more than one signaling pathway in relation to the release of histamine. The different modulatory effects of bicarbonate on the release of histamine must be due to the different mechanisms related to PMC. Therefore, based on this study, MPH has the capability to minimize an immune disorder, and reduce or eliminate the allergic reaction caused by OVA.

\section{CONCLUSIONS}

Milk protein hydrolysates in this study had the capacity to enhance immunity and reduce the risk of an allergic reaction in vivo. The MPH enhanced immunity in mice by stimulating host immunity, which increases the weight of certain immune system organs, raises the level of hemolysin in serum, and enhances the phagocytosis of macrophages. In addition, it was revealed that $\mathrm{MPH}$ reduced levels of $\mathrm{IgE}$, IL-4 in serum, and histamine and bicarbonate in PMC, as well as enhancing TGF- $\beta$ levels in the serum of OVA-sensitized mice. Our results suggest that $\mathrm{MPH}$ is a potent immune-enhancing agent with low allergenicity. The investigation of the effect of MPH on milk allergies provided evidence for the development of low-allergy milk products.

\section{ACKNOWLEDGMENTS}

This work was supported by the Natural Science Funding of China (41276121) and the Science and Technology Department of Zhejiang Province (Z3110211), the Science and Technology Department of Ningbo University (2012B82017, 2011C11017), and the K. C. Wong Magna Fund at Ningbo University.

\section{REFERENCES}

Amdekar, S., P. Roy, V. Singh, A. Kumar, R. Singh, and P. Sharma. 2012. Anti-inflammatory activity of lactobacillus on carrageenaninduced paw edema in male Wistar rats. Int. J. Inflamm. 2012:16.

Caffarelli, C., F. Baldi, B. Bendandi, L. Calzone, M. Marani, and P. Pasquinelli. 2010. Cow's milk protein allergy in children: A practical guide. Ital. J. Pediatr. 36:5.

Caira, S., R. Pizzano, G. Picariello, G. Pinto, M. Cuollo, L. Chianese, and F. Addeo. 2012. Allergenicity of milk proteins. Chapter 7 in Milk Protein. W. Hurley, ed. InTech, Rijeka, Croatia. $10.5772 / 52086$.

Cao, X. Y., P. Daodong, P. Tao, and Z. Xiaoqun. 2012. Milk protein hydrolysis for peptide production and reduce the allergy of milk protein. J. Chin. Inst. Food Sci. Technol. 2:7-14.

Chen, Y., J. B. Tang, X. Wang, F. X. Sun, and S. J. Liang. 2012. An immunostimulatory polysaccharide (SCP-IIa) from the fruit of Schisandra chinensis (Turcz.). Int. J. Biol. Macromol. 50:844-848.

Cheng, X. Q., H. Li, X. L. Yue, J. Y. Xie, Y. Y. Zhang, H. Y. Di, and D. F. Chen. 2010. Macrophage immunomodulatory activity of the polysaccharides from the roots of Bupleurum smithii var. parvifolium. J. Ethnopharmacol. 130:363-368.

Eriksen, E. K., G. E. Vegarud, T. Langsrud, H. Almaas, and T. Lea. 2008. Effect of milk proteins and their hydrolysates on in vitro immune responses. Small Rumin. Res. 79:29-37.

Gavett, S. H., D. J. O'Hearn, X. M. Li, S. K. Huang, F. D. Finkelman, and M. Wills-Karp. 1995. Interleukin 12 inhibits antigen-induced airway hyperresponsiveness, inflammation, and Th2 cytokine expression in mice. J. Exp. Med. 182:1527-1536.

Godkar, P. B. 1996. Acid-base balance. Pages 252-257 in Textbook of Medical Laboratory Technology. 11th ed. Bhalani Publishing House, New Delhi, India. 
Gordon, B. R., D. S. Hurst, J. A. Fornadley, and D. H. Hunsaker. 2013. Safety of intradermal skin tests for inhalants and foods: A prospective study. Int. Forum Allergy Rhinol. 3:171-176.

Høst, A., B. Koletzko, S. Dreborg, A. Muraro, U. Wahn, P. Aggett, J. L. Bresson, O. Hernell, H. Lafeber, K. F. Michaelsen, J. L. Micheli, J. Rigo, L. Weaver, H. Heymans, S. Strobel, and Y. Vandenplas. 1999. Dietary products used in infants for treatment and prevention of food allergy. Arch. Dis. Child. 81:80-84.

Johansson, S. G., J. O. Hourihane, J. Bousquet, C. Bruijnzeel-Koomen, S. Dreborg, T. Haahtela, M. L. Kowalski, N. Mygind, J. Ring, P. van Cauwenberge, M. van Hage-Hamsten, and B. Wuthrich. 2001. A revised nomenclature for allergy. Allergy 56:813-824.

Kessel, A., and I. Dalal. 2011. The pendulum between food protein-induced enterocolitis syndrome and IgE-mediated milk allergy. Acta Paediatr. 100:e183-e185.

Khodoun, M. V., R. Strait, L. Armstrong, N. Yanase, and F. D. Finkelman. 2011. Identification of markers that distinguish IgEfrom IgG-mediated anaphylaxis. Proc. Natl. Acad. Sci. USA 108:12413-12418.

Komai-Koma, M., F. Brombacher, P. N. Pushparaj, B. Arendse, C. McSharry, J. Alexander, R. Chaudhuri, N. C. Thomson, A. N McKenzie, I. McInnes, F. Y. Liew, and D. Xu. 2012. Interleukin-33 amplifies IgE synthesis and triggers mast cell degranulation via interleukin-4 in naive mice. Allergy 67:1118-1126.

Korhonen, H. 2009. Milk-derived bioactive peptides: From science to applications. J. Funct. Foods 1:177-187.

Mahajan, S. G., and A. A. Mehta. 2010. Immunosuppressive activity of ethanolic extract of seeds of Moringa oleifera Lam. in experimental immune inflammation. J. Ethnopharmacol. 130:183-186.

Nakamura, K., S. Ogawa, K. Dairiki, K. Fukatsu, H. Sasaki, T. Kaneko, and T. Yamaji. 2011. A new immune-modulating diet enriched with whey-hydrolyzed peptide, fermented milk, and isomaltulose attenuates gut ischemia-reperfusion injury in mice. Clin. Nutr. 30:513-516.

Ogawa, K., T. Nabe, H. Yamamura, and S. Kohno. 1999. Nanomolar concentrations of neuropeptides induce histamine release from peritoneal mast cells of a substrain of Wistar rats. Eur. J. Pharmacol. 374:285-291

Ohta, Y., K. Yashiro, M. Hidaka, M. Honda, Y. Imai, K. Ohashi, and K. Fukuzawa. 2012. A single exposure of rats to water-immersion restraint stress induces oxidative stress more severely in the thymus than in the spleen. Redox Rep. 17:200-205.
Oviedo-Boyso, J., J. J. Valdez-Alarcon, M. Cajero-Juarez, A. OchoaZarzosa, J. E. Lopez-Meza, A. Bravo-Patino, and V. M. Baizabal-Aguirre. 2007. Innate immune response of bovine mammary gland to pathogenic bacteria responsible for mastitis. J. Infect. 54:399-409.

Picariello, G., P. Ferranti, O. Fierro, G. Mamone, S. Caira, A. Di Luccia, S. Monica, and F. Addeo. 2010. Peptides surviving the simulated gastrointestinal digestion of milk proteins: Biological and toxicological implications. J. Chromatogr. B Analyt. Technol. Biomed. Life Sci. 878:295-308.

Playford, R. J., C. E. Macdonald, and W. S. Johnson. 2000. Colostrum and milk-derived peptide growth factors for the treatment of gastrointestinal disorders. Am. J. Clin. Nutr. 72:5-14.

Shek, L. P. C., L. Bardina, R. Castro, H. A. Sampson, and K. Beyer. 2005. Humoral and cellular responses to cow milk proteins in patients with milk-induced IgE-mediated and non-IgE-mediated disorders. Allergy 60:912-919.

Silvestre, M. P. C. 1997. Review of methods for the analysis of protein hydrolysates. Food Chem. 60:263-271

Stelwagen, K., E. Carpenter, B. Haigh, A. Hodgkinson, and T. T. Wheeler. 2009. Immune components of bovine colostrum and milk. J. Anim. Sci. 87(Suppl.):3-9.

Sugimoto, Y., H. Ohishi, T. Toyota, and C. Kamei. 1998. Strain differences in histamine release from peritoneal mast cells in rats. Gen. Pharmacol. 31:613-616.

Thakur, M., S. Bhargava, and V. K. Dixit. 2006. Immunomodulatory activity of Chlorophytum borivilianum Sant. F. Complem. Altern. Med. 10:1-5.

Vilariño, N., M. R. Vieytes, J. M. Vieites, and L. M. Botana. 1999 Modulatory effect of $\mathrm{HCO}_{3}{ }^{-}$on rat mast cell exocytosis: Crosstalks between bicarbonate and calcium. Biochem. Biophys. Res. Commun. 260:71-79.

Wu, X., G. Mao, Q. Fan, T. Zhao, J. Zhao, F. Li, and L. Yang. 2012. Isolation, purification, immunological and anti-tumor activities of polysaccharides from Gymnema sylvestre. Food Res. Int. 48:935-939.

Zaleski, M. B., H. R. Thacore, P. Zhou, S. Dubiski, S. Nakeeb, and R. K. Cunningham. 1995. Retrovirus-induced lymphoproliferative disease in mice: Role of humoral immunity in perinatally exposed mice. Immunobiology 194:390-402. 